Mihók Sándor ${ }^{1}$

\title{
A szegények gondozása ("hadigondozás") az ókori Hellászban és a Római Birodalomban
}

\section{Caring for the Poor (Military Solicitude) in Ancient Hellas and in the Roman Empire}

\begin{abstract}
Absztrakt
A tanulmány célja, hogy bemutassa a szegénygondozás és a "hadigondozás" történelmi fejlödését az ókori Hellászban és a Római Birodalomban. A dolgozat áttekinti a szegénygondozás (hadigondozás) rendszerének alapvetö funkcióit, beleértve a hasonlóságokat és különbségeket a természetbeni ellátások és pénzbeli kifizetések között, valamint felvázolja a korszak egyesületeinek és alapitványainak szerepét. A cikk hasznos lehet mindazok számára, akik -általános -áttekintést szeretnének kapni a kor (hadi)rokkantjai, özvegyei és árvái ellátásáról.
\end{abstract}

Kulcsszavak: szegénygondozás, hadigondozás, hadirokkant, járadék és juttatás

\begin{abstract}
The aim of the study is to show the historical development of caring for the poor especially military solicitude from the Ancient Near East to the Ancient Hellas and the Roman Empire. This paper presents the basic functions of the poor law systems (military solicitude), including the similarities of and differences between their in-kind benefits and pension payments and also outlines the prominent roles of the ancient associations and
\end{abstract}


foundations. The article could be useful for all those who want to have a general overview of the disabled veterans', widows' and orphans' pensions and benefits.

Keywords: caring for the poor, military solicitude, disabled veteran, pension and benefit

\section{Bevezetés}

A szegények, betegek és elesettek gyámolítása, védelme az emberiséggel egyidős. A szociális gondoskodás formáit és megvalósulásának módjait az adott kor szokásrendszere, a változó gazdasági és társadalmi fejlettség, a különböző filozófiai és ideológiai elképzelések, az egyén társadalomban betöltött szerepe és annak értéke alapvetően meghatározta. A hagyományos társadalmakban a védelmezés és a gondozás a család kötelessége volt, de időről időre, eltérő súllyal megjelentek az állam és a vallások által nyújtott szociális tevékenységek is. A szociális gondoskodás a változó és eltérő gazdasági és társadalmi alapokon más és más formában valósult meg. ${ }^{2} \mathrm{Az}$ ókori Hellászban és a Római Birodalomban az elesettekről, a háború áldozatairól, a rokkantakról, özvegyeikről és árváikról történő szociális gondoskodás, a mai fogalmak szerint a hadigondozás „távoli előzményének” tekinthető. Azonban ezek az intézmények nem az ókori görög és római állam- és jogfejlődés kizárólagos eredményeként jöttek létre. Előképeik az ókori Közel-Kelet különböző egymás melletti vagy egymást követő állam- és jogrendszerei közötti kulturális értékek, erkölcsi normák cseréje során alakultak ki. A csere és kölcsönhatás, az átvétel és a továbbadás révén a korai kelet jogából sok került át a hellén és a római világba, majd közvetítésükkel Európa és a világ jogi kultúrájába. ${ }^{3}$ Ezekben az egyiptomi, mezopotámiai, kisázsiai és Földközi-tenger melléki ókori közel-keleti (katona)államokban azonban még nem alakult ki intézményesült „szociálpolitika”. (A szociálpolitikáról csak I. Erzsébet angol uralkodó 1601-ben kiadott szegényügyi törvénye után szokás beszélni. ${ }^{4}$ ) Az ókori Közel-Kelet háborúi magasra emeltek és elpusztítottak birodalmakat, kisebb helyi hatalmakat. A katonai erő meghatározó módon alakította a gazdaságot, a békebeli erőviszonyok rendszere a kegyetlen és véres háborúkban alakult ki. Egy-egy közösség, társadalom gazdasági helyzetét, az erőforrásokhoz való hozzájutásának lehetőségeit és annak árát alapvetően hadseregének sikeressége vagy kudarca döntötte el. ${ }^{5} \mathrm{Az}$ agresszió, az eröszak és a háborúskodás így alapvetően meghatározta az ókori Közel-Kelet, Hellász és Róma hétköznapjait. Azonban a háborúk utáni időszakokban olyan mértékű volt a felnőtt, munkaképes korú férfinépesség csökkenése, hogy a kisközösségi/családi rendszer már nem tudta ellátni a rokkantak, özvegyek és árvák sokaságát. Mivel az államoknak nem volt érdeke nincstelenek és koldusok hadával veszélyeztetni a közbiztonságot, így az uralkodók - tehát ebben a formájában az állam - és a templom - azaz

\footnotetext{
Rostáné Riez Andrea: A közösségi gazdálkodás érvényesítése a szociális szolgáltatások területén, különös tekintettel a családok támogatására, Doktori (PhD) értekezés, Nyugat-magyarországi Egyetem, Sopron 2014, 19. http://doktori. nyme.hu/461/19/rostanerieza_disszertacio.TextMark.pdf (Letöltve: 2018. 04. 10.)

Hajdu Lajos et al.: Általános jogtörténet, Tankönyvkiadó, Budapest, 1991, 62.

Lakner Zoltán: Szociálpolitika (PPKE Vitéz János Kar), Szent István Társulat, az Apostoli Szentszék Könyvkiadója, Budapest, 2012, 18. https://btk.ppke.hu/uploads/articles/288257/file/Szocpol.pdf, (Letöltve: 2018. 04. 10.)

Kalla Gábor: Háború és béke az Ókorban, Múlt-kor Történelmi Magazin, 2010, http://mult-kor.hu/20100518_haboru_es_beke_az_okorban (Letöltve: 2018. 04. 10.)
} 
az egyházak - is részt vállaltak a fedél és szülői felügyelet nélkül maradt gyermekek neveléséből és tanításából, az özvegyek támogatásából és később a munkaképtelenek, valamint a rokkant katonák ellátásából. ${ }^{6}$

\section{A szegénység megítélése a hellén világban}

A klasszikus ókort, az antikvitást a kultúra bölcsőjének tekintik. Ebben az időben alapozódott meg kontinensünk társadalmi, politikai és szellemi fejlődése. Hellászban a városállamok kialakulásával párhuzamosan jött létre az egyeduralmat felváltó arisztokratikus hatalmi szerkezet. Ez lehetővé tette a vélemények versengését, ami a teokratikus és más - korábbi ókori közel-keleti - uralmi rendszerekben egyáltalán nem volt lehetséges. ${ }^{7}$ A továbbiakban a terjedelmi korlátokra való tekintettel mellőzöm a részletes földrajzi bemutatást, a jog és kultúrtörténeti korszakmeghatározást és a hellén világot, az ókori Hellászt a szegénygondozás fejlődésén keresztül kívánom röviden bemutatni.

Előzetesen azonban tisztáznunk kell, hogy a szegénység fogalmához az ókori Hellászban számos negatív társadalmi sztereotípia kapcsolódott. Arisztotelész szerint: "a szegénység polgári viszályt szít, és a bün kiváltó okává válik". ${ }^{8}$ Hérodotosz pedig egyenesen a hellének egyik közös sajátosságának nevezi a szegénységet. Ez a szegénységet és a bünt egyfajta szinonimaként kezelő felfogás az antikvitás évszázadai során szinte semmit sem változott. ${ }^{9}$ Azonban ezekben a századokban szintén töretlenül érvényesült az az álláspont is, amely a gazdagság ${ }^{10}$ megléte alapján eleve feltételezett minden "nemes erényt". ${ }^{11}$ A hellénisztikus poliszok társadalomtörténetének az egyik legfontosabb jellemzője a polgárságon belüli társadalmi különbségek növekedése volt. Bár a polisztársadalmakat már a klasszikus korban is egy szűk vagyonos felső réteg dominanciája jellemezte, ez a különbség a hellénisztikus korban tovább növekedett: a politikai, katonai, papi tisztségek betöltése úgyszólván teljesen a vagyonos elit privilégiumává, illetve, ahogyan az érintettek nem ritkán érezték, kötelességévé vált. ${ }^{12}$

6 Berzsenyi Emese: A társadalmi gondoskodás és tanítás történelmi előképei, Iskolakultúra, 25 (2015/9) 100-110. http:// epa.oszk.hu/00000/00011/00197/pdf/EPA00011_iskolakultura_2015_09_08.pdf (Letöltve: 2018. 04. 10.)

Martina Boden: Krónika Kézikönyv: Európa, Magyar Könyvklub, Budapest, 2001, 17.

8 Szlávik Gábor: „A szegények mindig veletek lesznek” - a szegénység fogalma és társadalmi értékelése az antik szerzőknél, az újszövetségi iratokban és a Kr. u. I-III. század keresztény gondolkodóinál, Egyháztörténeti Szemle, 8 (2007/2) 17., 34. http://egyhaztortenetiszemle.hu/wa_files/eSzemle2007-2.pdf (Letöltve: 2018. 04. 10.)

9 Megjegyzést érdemel, hogy Platón másként vélekedett a szegénységről: „[...] Plató, a nagy görög bölcs, már látja a bajokat és így ír »Az állam vagy az igazságosról« c. munkájában: »ne csak egy osztály legyen boldog mindenekelőtt, hanem lehetőleg az egész állam. " Lásd: Pálos Károly: Szegénység Szegénygondozás, Martineum Könyvnyomda Rt., Szombathely, 1934, 11. http://mtdaportal.extra.hu/books/palos_karoly_szegenygondozas.pdf (Letöltve: 2018. 04. 10.); Platón kortársa, a cinikus mozgalom legismertebb gondolkodója, Diogenész is eltérő elveket vallott a szegénységről. Azt vallotta, hogy nincs szükség vagyonra, csak az elemi szükségletek kielégítésére és ezért szegénységi fogadalmat is tett. Szoboszlai-Kiss Katalin: A hellenizmus filozófiai mozgalmainak gyökereiről, A kisebb szókratikus iskolák, Jog-Állam -Politika, 3 (2011/4) 145. http://dfk-online.sze.hu/images/J\%C3\%81P/2011/4/szoboszlai.pdf (Letöltve: 2018. 04. 10.)

10 A klasszikus, majd a hellénisztikus kori közgondolkodás például csak azt tartotta „gazdagnak”, aki pusztán csak a vagyonából meg tudott élni. Mindenki más, akinek munkával, vagy munka jellegű tevékenységgel kellett hozzájárulnia önnön fenntartásához, ugyancsak e felfogás szerint „szegénynek” számított. Lásd: Szlávik (2007): i. m. 20.

11 Szlávik (2007): i. m. 38.

12 Kató Péter: Illúziók a hellénisztikus polisokban, Ókor folyóirat az antik kultúrákról, 16 (2017/1) 14. http://okorportal.hu/ folyoirat/archivum/2017-xvi-evfolyam/20171-illuziok (Letöltve: 2018. 04. 10.) 
Ennek a helyzetnek a kifejeződése az euergetizmus ${ }^{13}$ jelensége. A szegényekkel történő gondoskodásról alapvetően a keresztény ókor kezdetétöl beszélhetünk. A Kr. u. 1. század utolsó harmadának lassan formálódó keresztény közösségeiben már nem keltett megütközést a szegénység. Istentöl rendelt állapotnak számított, nem csak a kiválasztottság jelévé, hanem egyfajta morális értékhordozóvá is vált.14

\section{A szociális gondoskodás kialakulása az ókori Hellászban - a polgárok adományai, az alapítványok és az egyesületek}

Az előzőkben már említettük, hogy a társadalom vezető rendjeit alkotó gazdagok mindenkor lenézték, de még inkább megvetették a szegényeket. A korai Hellász arisztokratikus berendezkedésủ államaiban a szegénységgel együtt járó gyatra életminőségtől eltekintve mindenekelőtt azért, mert a szegénység fogalmához többnyire a másoknak való alávetettség fogalma társult. Mai szemmel megdöbbentő, hogy a gazdagok csak a halált tartották rosszabbnak a mások gyarapodását szolgáló bérmunkánál. ${ }^{15}$ Érdekesség, hogy a szegényeknél is rosszabb megítélésü - és az archaikus kori Hellász egyik jellegzetes alakjának számító - nyomorban tengődő koldus, bár rövid időre, a vendégjog egy pontosan körülhatárolt minimumában részesült, amely a szegényeket egyáltalán nem illette meg. Ennek a hátterében a korszak azon vallási hiedelme állt, amely szerint, aki „rosszat tesz" egy koldussal arra az istenek bosszúja száll. ${ }^{16} \mathrm{~A}$ pogány ókor, ha ismerte is a "kisemberek" között megnyilvánuló szolidaritást, sajátos elveket vallott az adomány majdani viszonzására a távoli jövőben sem képes nincstelenek segélyezéséről. „Aki adott, annak adj, de ne adj annak, aki nem adott" - ezt a gyakorlati tanácsot adta már Hésziodosz is, a Kr. e. 7. századi boiótiai parasztköltő. ${ }^{17} \mathrm{~A}$ korai időszakra jellemző altruisztikus felfogást követően megjelent a koldusoknak, a szegény utazóknak és a hajótörött tengerészeknek adott alamizsnaosztás, azonban ezt a „jócselekedetet" az adakozó polgárok egyáltalán nem tartották fontosnak. Később általánossá vált, hogy a görög polgárok ruhákat adtak a rászorulóknak. Továbbá gabonahiány, illetve magas gabonaárak esetén a gazdag polgárok segítettek a kevésbé jómódú polgártársaiknak, azonban a terménysegélyt valójában nem a szegények kapták. A feljegyzések szerint, amikor az idősebb embereket a zsarnokság idején megfosztották a javaiktól, több tehetős ember az irántuk érzett szánalomtól vezérelve a saját vagyonából önkéntesen adományozott valamit

13 Az euergetizmus elsődleges magyarázata egy bizonyos ethosz, a „becsület-szégyen" mentalitás, amely tiszteletre méltó magatartást követelt az elittől, illetve a „philantropia”, az emberbaráti magatartás erénye. Az euergetizmus mai formája egy hosszú folyamat eredménye. Először a görög kultúra keretén belül jelent meg, ahol a társadalom működésének egyik alapfeltétele volt, azonban ekkor még nem a közjót szolgáló épületek (közfürdők, kórházak) megépítése révén váltak jótevővé az uralkodók, hanem már egy felszabadító rendelet is kiválthatta egy polisz rokonszenvét, és ott a jótevőt néhány esetben akár az istenek közé is emelték.

Tóth Krisztián: Nagy Heródes: zsarnok vagy jótevő? XX. reál- és humántudományi Erdélyi Tudományos Diákköri Konferencia (ETDK), Kolozsvár, 2017, 9. http://etdk.adatbank.transindex.ro/pdf/tothkrisztian.pdf (Letöltve: 2018. 04. 10.)

14 Szlávik (2007): i. m. 46-47.

Szlávik (2007): i. m. 29-30

Szlávik (2007): i. m. 15-16.

Szlávik (2007): i. m. 29. 
a szerencsétlenül járt polgártársnak. ${ }^{18}$ A jótékonykodás egyik közismert formája volt, ha egy jómódú polgár valamely - számára kedves - istenség tiszteletére létrehozott egy alapítványt. Az alapító vállalta, hogy az istenség tiszteletére tartott áldozati lakomák élelmiszereit (hús, olaj) biztosítja. A lakomán részt vevő meghívottak ezeket az élelmiszereket fogyasztották. A meghívottak között többnyire azok voltak, akik a szentély környékén laktak, de az idegenek és a rabszolgák sem voltak kizárva a lakomákból. A szegény polgártársak is részt vehettek ezeken az ünnepi eseményeken, de kifejezetten a szegényeknek létrehozott alapítvány nem létezett.

Ebből a korból ismert a templomi áldozati étkezés intézménye is. Ekkor a polgárok elsősorban a barátaikat hívták meg egy közös étkezésre, általában viszonossági alapon, a meghívottak között azonban alig voltak szegények. ${ }^{19}$

Később az ókori Hellászban fontos szerepet töltöttek be az egyesülési szabadság alapján létrejött „öngondoskodáson alapuló” eranosz egyesületek, amelyeknek a célja kezdetben az volt, hogy egy baráti társaság - amely kizárólag polgárjoggal rendelkező férfiakból állt - a közös étkezések költségeinek fedezésére pénzt adott össze. Az idők múlásával a közös cél átalakult és az egyesület működésének meghatározó feladata a nehéz anyagi helyzetbe került tagok segítése lett. Az alapítók az egyesület létrehozásához nagyobb összegű pénztőkével, ingatlanokkal és munkaerő biztosításával (jellemzően rabszolgákkal) járultak hozzá. A rendes (például belépési díj, havitagdíj) és a rendkívüli bevételek (örökségek, ajándékok, a tőke kamatai) biztosították az egyesület folyamatos működését. Az egyesület így kialakult vagyonát akkor lehetett felhasználni, ha a tagot vagy családtagját hadifogságból vagy adósrabszolgaságból kellett kiváltani, ha a tag lányát férjhez akarta adni vagy adósságának visszafizetését kellett támogatnia. A fenti célokra kiváltott összeget kamat nem terhelte. Továbbá a tag halála esetén az egyesület sírhelyet biztosított számára, valamint egyszeri pénzsegélyben részesítette a halott tag családját, amely pénzösszeget nem kellett visszatéríteni. A hellenisztikus korban ezekbe az egyesületekbe a polgárjoggal rendelkező férfiak mellett már külföldiek is beléphettek, sőt - kivételesen - rabszolgákat is felvettek az alacsonyabb rendü munkák elvégzésére. ${ }^{20}$ Említést érdemel még a „Pithagoreusok Egyesületeként" ismert magánkezdeményezés is, amely a Kr. e. 6. és 4. század között élte fénykorát, és amely a Kr. e. 1. században újraéledt. Az egyesület érdekessége az volt, hogy bár a tagok egymástól távol éltek, azonban, ha valamelyik tagnak segítségre volt szüksége, számíthatott a többiekre. A jótevő és a segítségre szoruló tag általában nem is ismerték egymást. ${ }^{21}$ Ez az egyesületi forma a keresztény szociális gondoskodás előképének is tekinthető. A szegények segélyezésének egyik elterjedt módja volt a korai idők keresztény gyülekezeteiben (is) a szeretetlakoma: az agapé. Ennek költségeit az egyházközösség gazdagabb tagjai viselték. Itt jóllakhattak a szegények (ide értve az özvegyeket és a teljességgel nincsteleneket is), és nem kellett üres gyomorral

18 Peter Lampe: Social welfare in the Greco-Roman world as a background for early christian practice, Acta Theologica, (2016) Suppl. 23:1-28, 7.www.scielo.org.za/pdf/at/v36s23/02.pdf (Letöltve: 2018. 04. 10.)

19 Lampe (2016): i. m. 9

20 Molnár Margit: Töredékek a szociális gondoskodás ókori történetéből, Esély, (1992/3) 99-100. www.esely.org/kiadvanyok/1992_3/toredekekaszocialis.pdf (Letöltve: 2018. 04. 10.)

$21 \quad$ Lampe (2016): i. m. 12. 
járulniuk az ezt követő úrvacsorához (eucharistia). ${ }^{22}$ Összefoglalva: elmondható, hogy az ókori Hellászban létezett a magánszemélyek körében a jótékonyság, bár a korai időszakból nem sok forrásra támaszkodhatunk. A klasszikus korban még az alamizsnára, a jótékonyságra és az adakozásra sem voltak egységes "szakkifejezések”, egészen addig, amíg a keleti és föleg zsidó hatásra azok a görög nyelv részévé nem váltak. ${ }^{23}$ Érdekesség, hogy - az archaikus időszakban - csak Hellász falusi közösségei biztosítottak az utazóknak ingyenes éjjeli szállást az arra kijelölt épületben, amelynek használatából a koldusokat sem zárták ki. Ezeket az épületeket napközben „közösségi házként" használták a falu polgárai. ${ }^{24} \mathrm{~A}$ polgárok tudomásul vették azt, hogy a termelőeszközökhöz való eltérő viszonyaik alapján a társadalmi termék elosztásából is egyenlőtlenül részesülnek. Ennek ellensúlyozására olyan szociális hálót fejlesztettek ki, amelynek fedezetét a leggazdagabbakra kirótt kötelezettségek, az úgynevezett „leiturgiák” jelentették. A tehetősek viselték például a nagyobb kiadással járó állami tisztségeket, továbbá hadihajókat szereltek fel, ünnepi játékokat rendeztek és a vallási ünnepeken vállalták a szegényebb polgártársak élelmezésével járó költségeket. ${ }^{25}$

\section{Az állam által nyújtott pénzbeli és természetbeni ellátások az ókori Hellászban}

Az ókori Hellászban kialakult szisztematikus állami szegénysegélyezés célja nem a megélhetési gondok enyhítése és még csak nem is a munkaképesség reprodukciójának biztosítása volt, hanem inkább az, hogy az elszegényedett szabadokat az államtól függő helyzetbe hozzák, és ezáltal irányíthatóvá tegyék. A Kr. e. 6. század környékén a városállamokban a polgárokat a közjó érdekében felhasználandó pénzadományok nyújtására biztatták. Parkokat építettek, valamint élelmiszert, ruhanemúket és más javakat gyűjtöttek össze a kezdetleges közintézményekben a szükséget szenvedők számára. ${ }^{26}$ Fontos kiemelnünk, hogy az összegyüjtött javakat az állam osztotta szét az általa érdemesnek tartottak között. A szociális gondoskodás vizsgálatakor az állam által nyújtott pénzbeli és természetbeni juttatásokat akként is lehetséges csoportosítani, hogy ezek mely fajtáit alkalmazták háború és béke idején.

Háború idején, mivel a városállamok nem tartottak fenn állandó zsoldoshadsereget, és a védelmet a polgárokból szerveződött hadsereg látta el, a ", hadigondozás" súlypontja a háborúban megrokkant polgárral, a háborúban elesett katona özvegyével, és hátramaradt, árva gyermekeivel való törődésre helyezödött. Hazatérése után Athénban minden háborús sebesült polgár - csekély összegü - jutalmat kapott, amit az állam pénzben fizetett ki, és ehhez járult természetbeni szolgáltatásként az ingyenes orvosi kezelés

\footnotetext{
Szlávik (2007): i. m. 50-51.

Lampe (2016): i. m. 12.

Lampe (2016): i. m. 20.

25 Rácz Árpád: Beszélgetés Kertész Istvánnal, (Az ókortörténet alapkérdései), Rubiconline, www.rubicon.hu/magyar/ oldalak/az_okortortenet_alapkerdesei (Letöltve: 2018. 04. 10.)

26 Kristó Katalin: Tervek és a valóság - A pénzbeli családtámogatási ellátások vizsgálata a kormányprogramok tükrében Doktori (PhD) értekezés Nemzeti Közszolgálati Egyetem Közigazgatás-tudományi Doktori Iskola Budapest, $2015,40$. http://ludita.uni-nke.hu/repozitorium/handle/11410/10314 (Letöltve: 2018. 04. 10.)
} 
és a gyógyuláshoz szükséges „gyógyszerek” biztosítása. ${ }^{27}$, Az özvegyek és az árvák felett az állam gyámságot vállalt. Bár a hadirokkantak özvegyei rendszeres támogatásban nem részesültek, az elárvult gyermekek neveltetése és pénzbeli ellátása a gyámi tisztség betöltésétöl nagykorúságuk (fiúk 18, lányok 14 év) eléréséig államköltségen történt. A lányok támogatása többnyire a férjhezmenetelükkor adott hozományból állt. Vitatott, hogy azok az árvák, akik apjukat nem a háborúban veszítették el, igényjogosultak voltak-e erre az ellátásra. A forrásokból úgy tűnik, legfeljebb azokra az esetekre ismerték el ilyenkor az igényjogosultságot, amikor az árva teljesen hozzátartozók nélkül maradt. Béke idején a pénzbeli juttatásokat kezdetben a magukra maradt testi fogyatékosoknak juttatott segélyek képezték. A Kr. e. 4. században, a perzsa háborúk után, ahogy létrejött az ókori „proletariátus”, úgy alakult át a kizárólag a háborús sérültekkel és a hátramaradottakkal törődő gondoskodás az öregek és munkanélküliek általános ellátásává. Megszünt a különbségtétel a civil és a katonai járadékos között. Társadalmi igény volt, hogy minden olyan athéni polgár állami támogatást kapjon, aki testi fogyatékossága következtében nem tud munkát végezni, és akinek nincs hozzátartozója. E jogosultság feltétele azonban meghatározott jövedelemhatárhoz kötődött. A jogosultságot egy alacsonyan megszabott vagyoni cenzus határozta meg: csak a 3 minánál (= 300 drachma = 1800 obulus) kisebb vagyonnal rendelkezők részesültek állami juttatásban. Ahogy Arisztotelész leírja saját kora állapotait: „Felülbírálja a tanács a munkaképteleneket is. Van ugyanis egy törvény, amely elrendeli, hogy a három minánál kisebb vagyonúakat, akik testileg annyira rokkantak, hogy nem képesek semmi munkát sem végezni, vizsgálja felül a tanács, és adjon az állam terhére eltartásukra mindegyiknek naponként két obulust. Ezek számára is van egy sorshúzással kijelölt kincstárnok."28 (Összehasonlításképpen: egy szarvasmarha értéke ekkor 36 ezer (!) obulus volt.) Az állami pénzbeli juttatás másik formája a görög polgárok számára a theorika, amit Periklész korától Kr. e. 339-ig a színházi előadások tartama alatt az államkasszából folyósítottak. Sokáig élt a szakirodalomban az a nézet, hogy a theorika színházi belépőjegy volt. Valóban akkor adták, azonban nem a jegy árát jelentette - mivel a színielőadások a Kr. e. 5. századig ingyenesek voltak - hanem tulajdonképpen az előadások idején kiesett kereset pótlására szolgált. A későbbiek során kiegészítője lett az államtól különböző címeken járó pénzbeli járadékok rendszerének, tehát köztisztséget vállaló polgár is részesülhetett belőle (ha egyébként

27 Szinai Alexandra: A szociális biztonsághoz való jog Miskolci Egyetem, Miskolc, 2013, 7-8. http://midra.uni-miskolc. hu/document/14318/6591.pdf (Letöltve: 2018. 04. 10.);

Említést érdemel, hogy az ókori Spártában hatalmas kultusza volt az egészséges és edzett testnek. Ugyanakkor, ha valakit valamilyen fogyatékosság ért a háborúban, vagy valamilyen fizikai munka következtében, akkor a fizikai fogyatékosságot nem kötötték össze a jellembelivel. Szepessyné Judik Dorottya: A hallássérült emberek magyarországi mozgalmának története nemzetközi kitekintéssel, in: Hegedüs Lajos et al.: A fogyatékosságügy hazai és nemzetközi története, Eötvös Loránd Tudományegyetem Bárczi Gusztáv Gyógypedagógiai Kar Budapest, 2009, 6.;

A gyógyszerek biztosításán túl az ókori Hellászban már megjelent a fogyatékos katonák kezdetleges rehabilitációja is. A Kr. e. 5. századból fennmaradt egy Hegisztratosz nevű harcos története, aki a fogságból a saját lába levágásával szabadult meg, majd falábbal később újra harcolni tudott.

Weinhoffer Judit: A katona-egészségügy szerepe a rehabilitáció XX. századi fejlődésében, Doktori (PhD) értekezés, Nemzeti Közszolgálati Egyetem, Hadtudományi Doktori Iskola, Budapest, 2017, 19. http://archiv.uni-nke.hu/feltoltes/ uni-nke.hu/konyvtar/digitgy/phd/2017/weinhoffer_judit.pdf (Letöltve: 2018. 04. 10.

28 Sarkady János: Szociálpolitika az ókori Athénben, História, 19 (1997/2) www.tankonyvtar.hu/en/tartalom/historia/97-02/ch02.html (Letöltve: 2018. 04. 10.) 
szűkölködött), sőt, a hadirokkantakat megillető pénzjavadalmakat is kiegészíthette. Arisztotelész a Kr. e. 4. században már 20 ezer polgárról beszél, akik valamilyen állami ellátásban részesültek. Athén ily módon nagymértékben megvalósította azt az eszmét, hogy a szabad polgárnak „állampolgári jogon" trophé, azaz állami életjáradék jár. ${ }^{29}$ A természetbeni ellátások az ókorban a rendes és a rendkívüli gabonaellátás formájában jelentek meg. Ez Hellász számára eleve kiemelkedően fontos kérdés volt, hiszen gabonabehozatalra szorult. Demoszthenész, amikor a macedón hadsereg megközelítette Athént - és éhínség fenyegette a városállamot - létrehozta a "gabonafelvásárló" tisztséget. A későbbiekben ez a - már a nép által választott - fontos tisztség a többi poliszban is elterjedt „állami gabonafelvásárló” néven. Ínséges időkben ugyanis meghatározták azt a gabonamennyiséget, amit a háztartások a birtokukban tarthattak, a fölösleget pedig mindenki köteles volt az állam rendelkezésére bocsátani.

A gabonaosztás béke idején a jómódú polgárok adományaiból, illetve az állami készletekből történt. Az állam által biztosított ingyenes gabonaosztásnak minden - polgárjoggal rendelkező - férfi részese volt. ${ }^{30} \mathrm{~A}$ rendszeres gabonaosztás rendjét törvény szabályozta, arra minden hónap elején került sor, és mindenki megkapta, aki azt előzetesen bejelentette a hatóságnál és személyesen jelentkezett érte. Minden polgár függetlenül anyagi helyzetétől és a családja létszámától ugyanarra a gabonamennyiségre volt jogosult. A szegénységben éló állampolgárság nélküliek azonban nem részesültek a gabonaosztásból. Athén továbbá szabályozta a piaci élelmiszerárakat is, ezzel is biztosítva, hogy azok mindenki számára elérhetők legyenek. ${ }^{31}$ Hellászban az állami ünnepek "munkaszüneti napnak" számítottak, azonban ezeken kötelező volt részt venniük az athéni polgároknak. Ezeken általában egy jeles katonai győzelmet (például a marathóni csata) ünnepeltek a polgárok. ${ }^{32}$ Az állam azzal tette "vonzóvá" a részvételt, hogy pénzt vagy ingyen belépőjegyet osztott, de csak a polgárjoggal rendelkezőknek. A költségeket az állam viselte és gyakran a polgárok mellett, az Athénba betelepülő idegenek (metoikoszok) is részesültek az áldozati állatok húsából tartott lakomákon. ${ }^{33} \mathrm{Az}$ állam a politikai életben - a népgyúlésen és az esküdtszéki bíráskodásban - való részvételt Periklész rendelkezései alapján anyagilag is támogatta. Az állampolgársággal rendelkező szegényebb kézművesek és kétkezi munkások is részesültek ebben az ellátásban, azonban az állampolgárság nélküli szegények ebböl is ki voltak zárva. ${ }^{34} \mathrm{Az}$ athéni állam a szegény polgárokat nem zárta ki a földszerzés („,kléruchia”) rendszeréből. Erre jó példa a Kr. e. 5. század közepén, a trák tengerparton alapított Brea gyarmatváros története. Az alapításról rendelkező néphatározatban ugyanis kimondták, hogy a gyarmatosítók kizárólag a szegényebb néposztályok soraiból kerülhetnek ki. ${ }^{35}$ Kevésbé ismert, hogy a Kr. e. 3. században állama régi dicsőségét Ágis spártai király egy földreformmal kívánta feléleszteni. A korszakban teljesen egyedülálló és merész elképzelésének lényege az volt, hogy a földeket államosítja

\footnotetext{
29 Molnár (1992): i. m. 97.

30 Periklész polgárjogi törvénye (Kr. e. 451-450.) csak a mindkét ágon athéni származású lakosoknak adta meg a polgárjogot. Ingyen gabonát csak az kapott, aki bizonyítani tudta athéni polgárságát. Lásd: Sarkady (1997): i. m.

31 Lampe (2016): i. m. 19.

32 Németh György: Görög ünnepek, História, 14 (1992/10) 3-4.

33 Lampe (2016): i. m. 20.

34 Lampe (2016): i. m. 21.

35 Sarkady (1997): i. m.
} 
és azokat a földnélküli, szegény lakosság körében felosztja. Kísérlete azonban elbukott, Ágist pedig kivégezték. ${ }^{36}$ Említést érdemel, hogy Athén nem csak anyagi juttatásban részesítette hadirokkantjait, hanem az ünnepi játékokon az első sorokban díszhelyet tartott fenn számukra, ezzel is kifejezve az állam háláját és nagyrabecsülését. ${ }^{37}$ Athénban azonban nem csak a hadirokkantakról, a hadiárvákról és a hadiözvegyekről gondoskodtak, hanem az elesett harcosok szüleiről is. Makedóniai Nagy Sándor pedig megparancsolta, hogy a háborúban elesett katonák árvái megkapják apjuk ki nem fizetett járandóságait. ${ }^{38} \mathrm{~A}$ továbbiakban áttérünk Hellász szellemi örökösének a Római Birodalomnak szegény- és hadigondozására.

\section{A szociális gondoskodás kialakulása a Római Birodalomban}

A Római Birodalomról szóló korabeli források nagy része a római belvízöblö-? val foglalkozik, a császárral, a császári családdal és a fényüző nagyvárosi élettel. A Birodalomban azonban a gazdagok és a mai kifejezéssel élve „szupergazdagok" a lakosságnak csak 0,5-1\%-át tehették ki. A lakosság nagyobb részének gazdasági viszonyairól, az alsó rétegek életmódjáról, bevételeiről és kiadásairól nagyon kevés hiteles forrásra támaszkodhatunk. Egyes gazdaságtörténészek szerint a Római Birodalom túlnyomó többsége nincstelen volt. Más ókortörténészek kissé árnyaltabb képet festenek a birodalom gazdaságáról és társadalmi összetételéről, de kétségtelen, hogy a Római Birodalom társadalmában igen jelentős volt a nehéz körülmények között élő földmüvesek és szegények számaránya. ${ }^{39}$ A továbbiakban vázlatosan áttekintjük a rómaiak szegénységről alkotott nézeteit. A római köztársaság legendás censora, az idősebb Cato (Kr. e. 2. század) Manius Curius Dentatust a Kr. e. 3. században élt hadvezért és államférfit tekintette legfőbb példaképének. ${ }^{40}$ Manius ugyanis miután közéleti szereplésétől visszavonult szerény birtokára azt saját kezével müvelte meg. A szegénységet egyáltalán nem tekintette szégyennek, és amikor erről faggatták kifejtette: "Szívesebben uralkodom gazdagokon, mint hogy magam legyek gazdag." ${ }^{41}$ Plautus - Cato kortársa - a híres komédiaíró ekként fogalmazta meg a nincstelenekről való gondoskodásról alkotott nézeteit: „Koldusoknak enni adni, s inni adni nem helyes: neked kár, s neki nyomorúságra nyújtod meg nyügös életét." ${ }^{42}$ Hasonlót állít a Kr. u. 1. század elején, a hanyatló köztársaság korában élő római történetíró, Sallustius is.

36 Kovács (Karner) Károly: Hellenizmus, Róma, zsidóság, Útitárs, Köln-Bécs, 1969, 37-38.

37 Takáts László: A Rákóczi-szabadságharc egészségügye, 2003, 44. http://mek.oszk.hu/05400/05419/05419.pdf (Letöltve: 2018. 04. 10.)

38 Josef Fischer: Welfare services for disabled veterans and surviving dependents in Classical Athens, Kraków 2017, 4., 18., http://independent.academia.edu/JosefFischer (Letöltve: 2018. 04. 10.)

39 Székely Melinda: Szegénység, gyermekszegénység az ókori Rómában, Szegedi görög füzetek 9., Közéleti és politikai viszonyok az antik világban, A Szegedi Görög Nemzetiségi Önkormányzat és a Csongrád Megyei Görögök Kulturális Egyesületének kiadványa a Szegedi Tudományegyetem Ókortörténeti Tanszékének közremüködésével, Szeged, 2015, 89. www.szegedigorogok.hu/szegedi-gorog-fuzetek-9/ (Letöltve: 2018. 04. 10.)

40 Sáry Pál: A mezőgazdasági munka erkölcsi elismerése az ókori Rómában, Miskolci Jogi Szemle, 12 (2017/2) 520. különszám, www.mjsz.uni-miskolc.hu/2017kulon2/51_sarypal.pdf (Letöltve: 2018. 04. 10.)

41 Manius Curius Dentatus, A Pallas nagy lexikona, www.arcanum.hu/en/online-kiadvanyok/Lexikonok-a-pallas-nagylexikona-2/cs-60BB/curius-dentatus-6790/ (Letöltve: 2018. 04. 10.)

42 Szlávik (2007): i. m. 33. 
Véleménye szerint: „a városi semmittevést a megélhetést épp csak biztosító mezei munkánál többre becsülő városi csőcselék (plebs urbana) nincstelen és rossz erkölcsű emberekből áll, akik a közösség kárára élősködnek." ${ }^{43}$ Ettől eltérő nézetet vallott a vagyonról és a gazdagságról a Kr. u. 1. század első harmadában alkotó Valerius Maximus, római szerző. Véleménye szerint: „[...] nem az tesz gazdaggá, hogy nagy a vagyonod, hanem az, hogy kevés a vágyad". ${ }^{44}$ A Kr. u. 2. század elsö, majd második harmadában a mediterrán térség páratlan virágzást élt meg, így a szegénységröl alkotott társadalmi kép is kissé árnyaltabbá vált. Ennek oka az, hogy a birodalom egészére kiterjedő jólét, s annak háttere, a korszak gazdaságának virágzása a század hatvanas éveinek vége felé közeledve még fenntarthatónak látszott. A több mint 3 millió $\mathrm{km}^{2}$-re kiterjedő Imperium Romanum megközelítőleg 70 vagy 80 millióra becsülhető lakossága - a távoli és látszólag szilárdan védett határok között - viszonylagos jólétben, de a korábbi időkhöz képest mindenképp békében és biztonságban élt. ${ }^{45} \mathrm{~A}$ hellénisztikus világ a vagyonból és az állami hatalom gyakorlásából egyaránt kizárta az alsóbb néprétegeket. A szegények válasza erre az adósság-elengedés követelése és a földek újrafelosztását kikényszeríteni kívánó program meghirdetése volt. Hasonlóképpen háttérbe szorította, majd mindinkább (negatív) megkülönböztetéssel kezelte szegénynek minősülő lakosságát az újtestamentumi korra már nem csak birodalmi méreteket öltő, de belső rendjében is mindinkább birodalommá szerveződő római állam is. Róma, amely egyének és csoportok szintjén biztositotta a társadalmi mobilitást, továbbra is fenntartotta a szegények tömegeinek a vagyonból és a hatalomból való kizártságát. ${ }^{46}$ Míg a pogány Római Birodalom gabonaosztással és vad cirkuszi játékokkal ${ }^{47}$ („,panem et circenses") igyekezett a tömeges szegénység szociális/gazdasági feszültségét megoldani, addig az új vallás követői: az őskeresztények - akik általában maguk is szegények voltak - már a vagyonukat is megosztották nélkülöző hittársaikkal. A hívők számának emelkedésével a vagyonközösség hamarosan megszűnt. Helyét az adakozás, a hívek áldozatkészsége foglalta el. A vagyonközösség maradványa a már korábban említett agapék, „szeretetlakomák” alakjában maradt fenn. A keresztényüldözések idején elsősorban azokat a rászorulókat segélyezték, akiket a hitük miatt üldöztek. ${ }^{48}$ I. Nagy Konstantin és Licinius társcsászárok Kr. u. 313-ban elismerték a korlátozások nélküli vallásszabadságot, a római államvallás pedig megszűnt. Ekkor kezdődött a kereszténység államvallássá történő megszilárdulásának folyamata, továbbá a korábbiaknál fejlettebb keresztény szegénygondozás („cura pauperum”) megjelenése.

43 Szlávik (2007): i. m. 34.

44 Szabó György: Sötétben tündöklöbb a fény. Római szállóigék és aforizmák, Dacia, Kolozsvár-Napoca, 1975, www. arcanum.hu/hu/online-kiadvanyok/Gondolattar-kristo-nagy-istvan-gondolattar-1/1800-elott-szuletett-szerzok-2/ valerius-maximus-i-szd-elso-ele-romai-tortenetiro-8A5/ (Letöltve: 2018. 04. 10.)

45 Szlávik Gábor: Egy elmaradott régió szerepvállalása a kor vallási mozgalmaiban: Közép-Phrygia montanizmusa, Egyháztörténeti Szemle, 7 (2006/1) 4. http://epa.oszk.hu/03300/03307/00013/index.htm (Letöltve: 2018. 04. 10.)

46 Szlávik (2007): i. m. 47

47 Például Augustus Kr. u 14-ben ekként számolt be a népnek tevékenységéről: „Négyszer segítettem ki az államkincstárt saját eszközeimmel úgy, hogy 150 millió sestertiust adtam át ennek a pénztárnak. Amikor a befolyt adók nem voltak elegendőek hamarosan 100000 embernek, s még ennél is többnek utaltam ki gabonát és pénzadományt saját magtáramból és vagyonomból." Boden (2001): i. m. 24.

48 Pálos (1934): i. m. 14-17. 


\section{A magánemberek helye, szerepe a Római Birodalom szegény- gondozásában, a kliens-patrónus viszony}

A Római Birodalomban példaértékünek tartották „a városi szegénység arra érdemes tagjai" irányába tanúsított figyelmet, a magánéleti szinten megnyilvánuló jótékonykodást, az alkalmi vagy rendszeres segélyezést. Továbbá birodalomszerte elterjedt volt, hogy a tehetősebb polgárok adományokat adtak (lásd: a korábban ismertetett euergetizmus). A támogatások formája széleskörü volt: például lakomák megtartása, különböző középületek felújítása, új könyvtár alapítása, vagy kisvárosi tanítók támogatása. ${ }^{49}$ A gazdag "római jótevőket” azonban legtöbbször a személyes haszonszerzés vezérelte, amely általában egy magasabb állami tisztség megszerzése volt. Mivel a „jótékonykodás" egyre nyíltabb szavazatvásárlássá fajult, az állam számos törvénynyel igyekezett azt több-kevesebb sikerrel szabályozni. ${ }^{50} \mathrm{~A}$ továbbiakban vázlatosan áttekintjük a kliens-patrónus viszonyt, amely egy kivételes intézménye volt a római világnak. Már Horatius és Vergilius is azt vallotta - némi költői túlzással -, hogy a római népet a gyakorlati élet kérdései és feladatai érdekelték mindenkor. Alapvetően nem a szépet, hanem a hasznosat keresték és az élet eszményi vonásaiért soha sem rajongtak túlságosan. A költők szerint a rómaiak világra szóló nagy elhatározásai és tettei legtöbbször az önzésből fakadtak. Annál inkább meglepő egy olyan intézmény, amelyben a gyakorlatiasság mellett „felemelö és eszményi” mozzanatokkal is találkozunk.

"Ilyen - régi alakjában - a clientela is, egy úrnak - a patronusnak - s egy vagy több egyénnek - a clienseknek - az a kölcsönös hủségen alapuló s a kölcsönös támogatásra célzó viszonya, melyet talán leginkább a középkori hübérurak s hübéresek, illetve jobbágyok közti viszonyhoz hasonlíthatnánk." ${ }^{11}$ Az idő múlásával természetesen a klientúra ősi rendszere is átalakult. A Kr. u. 1. század derekán az Imperium Romanum lakosságának túlnyomó részét kitevő szegények állandó társadalmi megaláztatásoknak voltak kitéve. Köztük a római szegények egyik sajátos csoportját alkotó kliensek is. luvenalis, római költő szerint a „más kenyerén élo”” - tudniillik a szolgálatai fejében olykor szerény ebédben, ám inkább csak élelmiszersegélyben vagy pénzadományban (sportula) ${ }^{52}$ részesülő - kliensnek annyi megaláztatást kellett patrónusától eltürnie, hogy sorsánál még a koldusé is jobb volt. ${ }^{53}$ Természetesen a korszak római kisemberei ezt nem tartották annyira lealacsonyítónak, figyelemmel arra, hogy az állami élelmiszersegélyen (annonae) kívül ez volt az egyik fő megélhetési forrásuk. A sportula maximális összegét a szokás alakította ki. Azonban ha valaki ügyes volt, akkor két-három pártfogóra is szert tett - azért, hogy minél több sportulát kapjon - és így az egyik patrónus esetleges távolléte alatt is valamilyen pénzforráshoz jutott. A kisember, a kliens, ezért a pénzért

9 Székely (2015): i. m. 98.

50 Lampe (2016): i. m. 10.

51 Holczhammer János: A clientela valószínü eredete, mivolta és fejlödése a római köztársaság korában, A dunántúli evangélikus egyházkerületi lyceum, államilag segélyezett főgymnasium és bölcsészet-theologiai főiskola értesítője az 1900/1901. évi tanévröl, Röttig Gusztáv Könyvnyomdája, Sopron, 1901, 3-4. https://library.hungaricana.hu/hu/ view/Sopron_31441_evangelikus_liceum_31491_1900/?query=patronus\&pg=2\&layout=s (Letöltve: 2018. 04. 10.)

52 A császárkorban a sportula már nem élelmiszersegély volt, hanem úgynevezett „zsebpénzzé" vált. Időnként a pártfogók ruhákkal és „extra” pénzzel egészítették ki a klienseik napi juttatását. Lampe (2016): i. m. 17.

53 Szlávik (2007): i. m. 39-40. 
voltaképpen különösebb szolgálatot nem is teljesített, reggelenként köszöntötte elökelő patrónusát, és ha kellett, kíséretének számát gyarapította. ${ }^{54}$

\section{Egyesületek az ókori Római Birodalomban}

A Római Birodalomban is megjelentek az egyesületek, a görög eranosz római megfelelője a temetési (collegia funeraticia), illetve a kisemberek gazdasági önsegélyezésére létrehozott (collegia tenuiorum) egyesület volt. Ezek az egyesületek a szegényebb sorsú polgárok önkéntes társulásai voltak abból a célból, hogy tagjaik számára temetésről gondoskodjanak, illetve önsegélyező pénztárként átmeneti segélyt nyújtsanak azoknak a tagoknak, akik baleset vagy betegség következtében nehéz anyagi helyzetbe kerültek..$^{55}$

Az egyesületek alapítása kezdetben nem volt semmilyen engedélyhez kötve, de a korrupció miatt az olyan egyesületek létesítéséhez, amelyek taggyülés létrehozását igényelték szenátusi jóváhagyásra volt szükség. E szabályok nyilvánvalóan a polgárok gyülekezési szabadságát szerették volna korlátozni. Említést érdemel, hogy Marcianus egyik császári rendelete ugyan tiltotta, hogy a katonák egyesületeket alakítsanak, de a "kegyes” császár méltányosságból kivételt tett: „a szegény sorsúaknak megengedett, hogy havi hozzájárulást adjanak össze, de havonta csak egy alkalommal (!) gyülhetnek össze, nehogy ennek ürügyén valamiféle tilos egyesületeket hozzanak létre". ${ }^{56}$ Érdekesség, hogy a Kr. u. a 3. században Hadrianus császár, aki jelentős hadseregreformokat hajtott végre, az altisztek számára engedélyezte, hogy úgynevezett "önsegélyező egyesületet" alakítsanak. ${ }^{57}$

54 Ürögdi György: Róma kenyere, Róma aranya, Gondolat kiadó, Budapest 1969, 160.;

Quintus Tullius Cicero, az ókor leghíresebb szónokának Marcus Tullius Ciceronak az öccse írta: A hivatalra való pályázás kézikönyvecskéje („Commentariolum petitionis”) című művet, amely a történelem első kampánystratégiai összefoglalása. A ma is korszerűnek számító müben az író bátyjának kívánt tanácsokat adni azokról a „fortélyokról”, hogy miként lehet consul. Művében kifejti, hogy az üdvözlők (salutatorok), a lekísérők (deductorok) és az állandó kíséret (assectatorok), vagyis a kliensek alkalmazása nélkül nem lehet győzni. Ebben a korszakban voltak olyan politikusok is, akik hiányzó kíséretüket pénzen bérelt assectatorok hadával pótolták. Ezt a lex Calpurnia (Kr. e. 67) éppúgy tiltotta, mint azt, hogy a jelölt ingyenjegyeket osszon a gladiátorviadalokra, vagy a népet hatalmas, kollektív lakomákon vendégelje meg. Németh György: Hogyan nyerjük meg a választásokat? Politikai propaganda a köztársaságkori Rómában, Médiakutató, 2005 tavasz, www.mediakutato.hu/cikk/2005_01_tavasz/01_hogyan_nyerjuk/ (Letöltve: 2018. 04. 10.) Brósz Róbert - Pólay Elemér: Római jog, Tankönyvkiadó, Budapest 1991, 176.

Molnár (1992): i. m. 100.

7 Az altiszti egyesület neve: collegium, vagy schola volt. A korabeli források szerint, ilyen volt a legio III. Augusta altisztjeinek egyesülete Lambaesisben. Az egyesület szabályzata szerint a tagok megállapított tagsági dijat - scamnarium - fizettek. Az így befolyt összegből minden tag egy elöre megállapított támogatásra volt jogosult, például tengeren túlra történő áthelyezése esetén útiköltséget, ha elöléptették felszerelési költséget kapott, amennyiben pedig veterán lett, akkor éves dijra volt jogosult. Buday Árpád: Római felirattan, Szerzői kiadás, Stief Jenő és Társa Könyvsajtója, Kolozsvár, 1914, 293. 


\section{A római veteránokat megillető jogosultságok és kiváltságok ${ }^{58}$}

Míg háború idején az ókori Hellászban a hadirokkantakról, hadiárvákról és veteránokról való gondoskodás sorrendisége alakult ki, addig Rómában a veteránokat illette meg elsődlegesen az állami gondoskodás. (Például Rómában a veteránok privilégiuma volt, hogy a városi, községi orvos ingyenesen kezelje és gyógyszerrel lássa el őket.) Rómában egészen Marius hadseregreformjáig (Kr. e. 107.) nem volt állandó, zsoldért harcoló hivatásos hadsereg. A hadsereget egy-egy hadjáratra a meghatározott vagyonnal rendelkező fegyverforgató férfi polgárok közül sorozással állították fel. A polgárok közjogi kötelezettségükként látták el a katonai szolgálatot. ${ }^{59} \mathrm{~A}$ szolgálatukat befejező katonákról történő gondoskodásról Marius afrikai hadjáratától kezdődően beszélhetünk, amikor a hadvezér már nem csak hivatásosokat, hanem római önkénteseket is bevetett. ${ }^{60}$ Ettől kezdve az „állami hadigondozás” középpontjába az életerejük teljében lévő leszerelt katonák, a veteránok végkielégitése és a polgári életbe való integrálása került. Röviden összefoglalva, áttekintjük, hogy az ókori Rómában kit tekintettek veteránnak. A köztársaság első időszakában a katona minden egyes hadjárat után hazamehetett, azonban ha gyalogosként 20 , lovasként pedig 10 hadjáratban részt vett, többé már nem volt behívható. Ezek hiányában 45, illetve 50 éves korban szűnt meg a hadkötelezettsége. Később, nevezetesen a második pun háború után, a katonát csak a háború befejezése után bocsátották el és 16, majd ezt követően 20 év lett a szolgálati idő. Ez utóbbit fenntartotta Augustus is, aki a szolgálati időt törvényesen rendezte és a húsz évi szolgálat a római uralom végéig kötelező volt, aki a legióban és Róma városi csapataiban (cohortes urbanae) katonáskodott. A praetorianusok 16 évig, a segédcsapatok (auxilia) katonái 25 évig, a „flottalegények" pedig még tovább, Philippus és Decius császár alatt 28 évig szolgáltak. ${ }^{61} \mathrm{~A}$ leszerelt veteránok jogosultsága a római polgárjog volt: kevésbé urbanizált területekröl érkezők katonai szolgálatuk befejeztével - jutalmul - római polgárrá (civitas Romana) váltak. A civitas Romana jogok és kötelességek sorát jelentette. Ide tartoztak a szavazati jog, a szerződéskötés joga, az érvényes házasságkötés joga, az öröklés joga, az adófizetés kötelezettsége, de még a tóga viselésének joga is csak a teljes jogú római polgárt illette meg. A leszerelők kiváltságai a végtisztesség, büntetések és közérdekű munkák területén mutatkozott

58 A veteránok (veterani) a római hadsereg kiszolgált katonái voltak, akik törvényes szolgálati idejük leteltével, tisztes elbocsátással (honesta missio) szereltek le csapatuktól. Az elbocsátás történhetett még testi fogyatkozás (sérülés, betegség) jogcímén (causaria missio), illetve megbecstelenítő vétség esetén (ignominiosa missio). Ez utóbbi esetén semmilyen juttatás nem járt. A honesta missióval elbocsátott veterán jogosult volt földjuttatásra (missio agraria) és/ vagy meghatározott összegü készpénzre (missio nummaria) - ezeknek az összefoglaló megnevezése volt a praemium militiae - továbbá különböző kedvezményekre (például adó elengedése, mérséklése). A szolgálati idő hossza, a juttatások köre és mértéke történeti korszakonként változott. Általánosságban elmondható, hogy a túlszolgálat sem volt kivételes intézmény, a szolgálati idő a császárkor végére lényegesen lerövidült. A causaria missióval leszereltek Caracalla császár uralkodásáig azonos kedvezményekben részesültek a honesta missióval elbocsátott társaikkal, ezt követően azonban legalább 20 év szolgálatra volt szükség a teljes ellátáshoz. Gabriele Wesch-Klein: Recruits and Veterans, in: Paul Erdkamp (ed.): A companion to the Roman Army, Blackwell Publishing Ltd., Oxford, 2007, 435-461.

59 Bajánházy István: Az állami pénzügyek a római köztársaságban, tansegédlet, 2014, 21-22. www.scribd.com/document/366110589/azallamipenzugyekromaikoztarsagbanbi2014 (Letöltve: 2018. 04. 10.)

60 Petruska Ferenc: Nemzetközi rekonverzió jogtörténete, Hadtudományi Szemle, 10 (2017/2) 511-512. http://real.mtak. hu/80371/1/17_2_alt_petruska_2.pdf. (Letöltve: 2018. 04. 10.)

61 Pecz Vilmos (szerk.): Ókori Lexikon, Dimissio, www.arcanum.hu/hu/online-kiadvanyok/Lexikonok-okori-lexikon-CA894/ (Letöltve: 2018. 04. 10.) 
meg. A katonák béréböl rendszeresen levontak bizonyos összeget, amely a temetési költségeket fedezte: ha békeidőben történt a haláleset, külön szertartás keretei között helyezték örök nyugalomra, ha háborúban, akkor általában a halottakat tömegesen égették el. Büncselekmények (delicta) elkövetése esetén a büntetés-végrehajtás során bizonyos büntetések (botozás, vadállatok elé vetés, bányamunka, hajóépítés) volt katonákkal és később gyermekeikkel szemben nem voltak végrehajthatók. Kiváltságos városba költözve a város polgárait megillető kiváltságok a veteránokat is megillették. Közmunkát viszont kötelesek voltak végezni. Adószedésre sem voltak kötelezhetők, de ha elvállaltak ilyen munkakört, akkor semmilyen megkülönböztetésben nem részesültek. ${ }^{62} \mathrm{~A}$ veteránok a polgári társadalomba való beilleszkedésének legföbb eszköze a kolóniákba való letelepítés volt, ami abból állt, hogy katonai rangjuknak megfelelö mennyiséget osztottak ki részükre a földparcellákból. ${ }^{63} \mathrm{~A}$ letelepítés indoka nem csupán „szociálpolitikai” volt, hiszen a kolonusszá vált veteránok a távoli birodalomrészeken is Róma megbízható támaszai maradtak, és talán az sem volt elhanyagolható szempont, hogy ezt a harcedzett tömeget biztonságpolitikai okokból is célszerü volt az örökös belvillongásokkal küszködő fővárostól távol tartani. ${ }^{64}$ Ezért már Sulla is támogatta hűséges katonáinak megjutalmazását. Még törvényt is hozott (lex Cornelia agraria), hogy „szerte Itáliában az egyes városokhoz tartozó nagy kiterjedésű, meg nem művelt, vagy büntetésként elkobzott földeket [...] a vele harcoló légió kiszolgált katonái között ossza szét." 65 Történelmi források szerint Kr. e. 59-ben Julius Caesar az állami kezelésben lévő termékeny campaniai földeket a három vagy többgyermekes veterán katonái között osztotta szét, és ezzel egy csapásra megvásárolta a tömegek szeretetét. ${ }^{66}$ Octavianus - a későbbi Augustus császár - a Kr. e. 1. században, azért harcolt, hogy Itáliában a sok ezernyi földbirtokostól kisajátított földet a triumvirek veteránjai számára megszerezze. A fellázadt földművesek felkelését a hadvezér kegyetlenül leverte, a földeket pedig a veteránok kapták meg. ${ }^{67}$ Augustus a későbbiekben sem feledkezett meg veteránjairól, uralkodása alatt magánvagyonából is áldozott a kiszolgált katonákra. ${ }^{68} \mathrm{~A}$ görög és latin nyelvű másolatok márványfeliratainak több városban feltárt töredékeiből rekonstruált, eredetileg Rómában felállított bronztáblák (Res gestae Divi Augusti) szerint az uralkodó a veterán katonák

62 Petruska (2017): i. m. 512-513.

63 Lampe (2016): i. m. 22.

64 Molnár (1992): i. m. 95.

65 Petruska (2017): i. m. 513.

66 Péter Orsolya Márta: „Alimenta” A családpolitika és a gyermekes családoknak nyújtott állami támogatás előképei a klasszikus Rómában, Sectio Juridica et Politica, Miskolc, Tomus XXIII/1. (2005) 98-99. www.matarka.hu/koz/ ISSN_0866-6032/tomus_23_1_2005/ISSN_0866-6032_tomus_23_1_2005_091-110.pdf (Letöltve: 2018. 04. 10.)

67 Aleksander Krawczuk: Római császárok, Interpress, Budapest, 1988, 23.

68 Augustus Kr. u. 6-ban egy katonai kincstárat (aerarium militare) is alapított a kiszolgált katonák végkielégítésének (praemia) finanszírozására, amelyet egy három évre kinevezett háromfős testület (praefecti aerarii militaris) irányított. A praetorianusok 16 évnyi szolgálat után leszereléskor 20 ezer sestertius egyszeri jutalmat kaptak, míg a legionariusoknak 20 évi szolgálatot követően 12 ezer sestertius praemium járt. Ezek az összegek egészen Caracalla uralkodásáig állandók maradtak. A katonai kincstár alapítását nem fogadta lelkesen a szenátus, ezért Augustus saját kincstárából 170 millió sestertius alaptőkét adományozott a kincstárnak, amit a provinciális városok és a kliens királyok adományai egészítettek ki. Azonban a tőke még így sem volt elegendő, és miután a szenátorok visszautasították az aerarium militare anyagi támogatását, Augustus elhatározta, hogy a kincstár állandó jövedelemforrását a kereskedelmi árukra kivetett 1\%-os forgalmi adóból (centesima rerum venalium), valamint az 5\%-os örökösödési adóból (vicesima hereditatium) finanszírozza. Grüll Tibor: A Római Birodalom gazdasága, Gondolat Kiadó, Budapest, 2017, 336-337. 
készpénzjutalmára és a részükre történő földvásárlásokra többszázmillió sestertiust áldozott. ${ }^{69}$ II. Constantius óta (Kr. u. 4. század) a sorozási minimuméletkor az átlagos jelentkezőknél a 18. életévben volt megállapítva. A 18. életév azonban nem mindenkire vonatkozott, mert a veteránok fiai apjuk által kedvezményekben részesültek, így nekik lehetőségük nyílott arra, hogy később jelentkezzenek az előírt szolgálatra. Miután a kedvezmények eltörlésének sikeresen ellenálltak, a veteránok fiai elérték, hogy az ő esetükben az irányadó a betöltött 20. életév legyen. ${ }^{70} \mathrm{~A}$ későrómai korból származó Codex Theodosianus és a Codex Justinianus néven ismert Kr. u. 5., illetve 6. századi nagy rendeletgyűjtemények katonai vonatkozású rendeleteiben is fontos szerepet kaptak a veteránokat megillető kiváltságok és juttatások. Ezek a szokatlan stílusban, párbeszédes formában megfogalmazott rendeletek a császár és katonái közötti meghitt viszonyt szemléltették. Jogtörténeti érdekesség, hogy a császár a veteránjaival való találkozáskor, a helyszínen tett rendeleti érvényü hatályos jogi nyilatkozatot, amely a korszakban nem volt általános gyakorlat. ${ }^{71}$

\section{Az állam által nyújtott pénzbeli és természetbeni ellátások, a keresztény szegénygondozás kezdetei}

Az ellátások áttekintése előtt fontos tisztáznunk, hogy Róma és Itália olyan száraz éghajlatú zónában helyezkedik el, ahol a rossz termés gyakori és szinte elkerülhetetlen volt, emiatt nehéz volt az emberek megélhetése. Róma gabonaellátása gyakran forgott veszélyben az időjárás kiszámíthatatlansága miatt. Háború idején súlyos válság alakult ki: a hadviselés zavart okozott a földmüvelésben, elvágta az utánpótlási vonalakat, egy hosszú háború alatt pedig lecsökkentek az állami tartalékok. A legújabb kutatások szerint a vidéki lakosság állandó alultápláltsága ugyan nem volt jellemző, de az időszakos éhezés

69 Németh György: Görög-római szöveggyüjtemény, Osiris Kiadó, Budapest, 2011, 158. fejezet, www.tankonyvtar.hu/ hu/tartalom/tamop425/2011_0001_520_gorog_romai_szoveggyujtemeny/ch158.html (Letöltve: 2018. 04. 10.)

70 Tóth László: Vegetius a sorozásról, Hadtudományi Szemle, 7 (2014/3) 211-212. http://epa.oszk.hu/02400/02463/00024/ pdf/EPA02463_hadtudomanyi_szemle_2014_03_208-215.pdf (Letöltve: 2018. 04. 10.)

71 "Legyen tehát kinyilvánítva, hogy magasságom - a felséges Constantinus - már most a következöket biztosította minden veteránnak: közülük senkire se háruljon semmiféle polgári szolgálat, sem közmunkateher, sem pedig városi vagy állami adószolgáltatás. Kereskedelmi tevékenységük után semmiféle illetéket nem tartoznak leadni. Az állami haszonbérlök is, akik ügynökeik útján jogtalan többletet szoktak behajtani, e veteránoktól távol maradjanak, hogy fáradalmaik után örökös nyugalmat élvezzenek. Kincstárunknak is ugyanezzel a levélbeli leirattal megtiltottuk, hogy bárkit is közülük háborgasson; szabadon vegyenek és adjanak el tehát, a legkedvezőbb üzleti feltételek mellett folytassanak pénzügyleteket és kereskedjenek, hogy kedvezményeiket korunknak e békéje és nyugalma közepette háborítatlanul élvezzék, semmiféle polgári, azaz testi vagy személyi szolgálat vagy vámteher ne sújtsa öket, hanem öregségüket a fáradalmak után nyugalomban töltsék." (Cod. Theod. VII. 20. 2 [320] = Cod. Just. XII. 46. 1)

„Minden kiérdemesült veteránnak házat adunk, melyet saját maga választ és örökös adómentességet ígérünk. A tulajdonos nélkül álló, vagy egyéb más földekböl vegyenek tulajdonukba szántókat a saját választásuk szerint és legyenek biztosítva, hogy földjük termése nekik lesz átengedve: semmiféle adót, semmiféle évenkénti beszolgáltatást nem követelünk; sőt inkább hozzátesszük, hogy földjeik megműveléséhez állatokat és magvakat is adunk, úgy, hogy annak, aki a testörségből távozott, két pár ökröt és mindkét terményfajtából száz vékát juttassanak, a többieknek pedig, akik kitüntetéssel vagy sebesüléssel szereltek le, egy-egy pár ökröt és mindkét terményből ötven vékát utaljanak ki. (Cod. Theod. VII. 20. 8. [364]) Hahn István: A hadművészet ókori klasszikusai, Zrínyi Katonai Kiadó, Budapest, 1963, 749-750. 
veszélye mindig fennállt. ${ }^{72} \mathrm{Az}$ ókori Hellászhoz hasonlóan Rómában is az állam pénzbeli és természetbeni ellátásai háború és béke idején járó szolgáltatásokra bonthatók. Béke idején a természetbeni juttatások - hasonlóan Hellászhoz - szintén az intézményes gabonaellátás formájában jelentkeztek, ami népélelmezési szempontokat szolgált, valamint nem utolsó sorban céljai közé tartozott a lakosság megnyerése a politika számára. A gabonaosztás igen nehéz feladatot jelentett, mivel Róma városának mintegy 250 ezer fös tömeget kellett ellátnia nap mint nap. Minden rászoruló római polgár jogosult volt havi - megközelítőleg - 33 kilogramm gabona vásárlására az államtól, kedvező és jóval a piaci ár alatti összegért. Ezt rögzítette a Kr. e. 123-ban a Gracchus nevéhez füződő törvény (lex Sempronia), amely meghatározta, hogy a polgárok milyen mennyiségü gabonát és milyen áron kaphattak havonta. ${ }^{73}$ Később a gabonajuttatások helyébe a panis civilis, vagyis a kenyérosztás lépett, amiből csak a római polgárjoggal rendelkezők és a szegények részesültek. Rómában is léteztek az egyfajta kereset-kiegészítésnek tekinthető pénzbeli juttatások, az úgynevezett congiariumok és a természetbeni gabonaosztások (annonae, illetve frumentationes). A vagyonos patrónusok pedig a szegényebb sorsú klienseknek ingyenes földhasználatot (precarium) engedélyeztek. A congiarium, eredetét tekintve tisztán természetbeni (például étolaj, bor, ritkábban gyümölcs, só, hús). Ezeket a frumentumhoz ráadásként osztogatták. A sokgyerekes családok többet kaptak, mint a gyermektelenek. Ezek az adományok nagyobb állami ünnepekhez, a császári család jelesebb eseményeihez, illetve a háborúkban aratott győzelmekhez s az azokat követő diadalmenetekhez kapcsolódtak. Forrásul a császár magánvagyona szolgált, azonban Caligula idejében a congiarium már rendszeres, államkincstárból fizetendő pénzjáradékká vált. Megemlítendő még a katonáknak járó különleges juttatás (donativa), ${ }^{74}$ valamint a pénzszórás a nép közé (missilia). ${ }^{75}$ Érdekes, hogy Suetonius, római levéltáros és életrajzíró a Kr. u. 2. században igen részletesen felsorolta, hogy mik is tartozhattak konkrétan a missilia körébe. A beszámoló szerint ennivalót, élelmiszer- és ruhautalványt, arany és ezüst tárgyakra, drágakőre, igazgyöngyre, festményekre, rabszolgákra (!), igavonó állatokra és szelídített vadállatokra beváltható utalványokat. Előfordult, hogy még teljesen új hajókat, bérházakat, földeket is kisorsoltak ilyen alkalmakkor. ${ }^{76} \mathrm{Az}$ antikvitás legátfogóbb és legszélesebb körben megszervezett állami támogatási rendszere az "alimentatio" volt. Az alimentatio egyértelmü célja az egyre aggasztóbb méreteket öltő itáliai népességcsökkenés megakadályozása volt, valamint az, hogy kedvező hitelekkel támogassa a kis- és középparasztságot. Azállami rendszer mellett magánalapitványok is létrejöttek alimentatiós célból. ${ }^{77} \mathrm{~A}$ rendszer azonban csak addig müködött, amíg a birodalom gazdasági helyzete stabil volt.

\footnotetext{
Székely (2015): i. m. 90

Szinai (2013): i. m. 13-14.

74 A katonák a késő római korban a fizetésük (stipendium) mellett ellátmányt (annona) és különleges juttatást (donativa) is kaptak. A donativát időszakonként ( 5 évente) fizették, illetve rendkívüli alkalmakkor (például a császár trónralépésekor, sikeres hadjáratok végén). Székely Melinda - Illés Imre Márton (szerk.): Késő római szöveggyűjtemény, JatePress, Szeged, 2013, 232.

75 Molnár (1992): i. m. 98-99.

76 Erdődy János: Qui missilia iactant in vulgus - A nép közé történő pénzszórás a római jogban, Pázmány Péter Katolikus Egyetem Jog- és Államtudományi Kara, Doktori Értekezések 11., Pázmány Press, Budapest, 2014, 38. http://mek.oszk. hu/17000/17014/17014.pdf (Letöltve: 2018. 04. 10.)

77 Például Alexander Severus császár Kr. u. 233-ban az anyja emlékére létrehozott egy szegény gyerekeket támogató magánalapítványt. Krawczuk (1988): i. m. 382.
} 
A Kr. u. 3. században bekövetkező súlyos válságot ez a korszakalkotó intézmény sem élte túl. ${ }^{78}$ Helyét az egyre inkább terjedő keresztény eszme szellemében fogant, főleg magánszemélyek kezdeményezésén és bőkezúségén alapuló úgynevezett „piae causae", kegyes célú alapítványok vették át. Ezek az alapítványok nem a családon belül élő szegény gyermekek segélyezését tűzték ki tevékenységük céljaként, hanem inkább lelenc- és árvaházként müködtek, befogadván az elárvult vagy a szülők által elhagyott gyermekeket. A piae causae rendszerint egy-egy kórházhoz vagy templomhoz kapcsolódva, tehát nem teljesen önálló szervezetrendszerben múködtek. Az egyre inkább keresztény eszmei alapokon álló római állam már nem támogatta minden erejével a születések számának növelését, azonban a megszületett gyermekek sorsát - igaz, nem közvetlenül, hanem a piae causae alapítását és fenntartását megkönnyítő jogi eszközökkel - a maga lehetőségeinek korlátain belül igyekezett javítani. ${ }^{79}$ Végül néhány gondolat az egyházi szegénygondozásról. Az egyházi adományszerzés legelterjedtebb módja a felajánlás (oblatio) volt. Általában gabonanemúeket, bort, olajat, mézet ajánlottak fel a hívek, és ezeket az adományokat a vasárnapi istentisztelet után osztotta ki a püspök. Az oblatio vasárnap történt, de egyes források szerint havonta egyszer külön felajánlás is volt. A felesleges adományokat elraktározták, hogy a napi szükségletet kielégíthessék. Csak azok kaptak segélyt, akiket a szegények nyilvántartásába felvettek. A kolostori élettel párhuzamosan kifejlődött a vendégbarátság intézménye, mivel a rendi szabályok szerint a szegények segítése és az idegenek befogadása, ellátása elsőrendü kötelességgé vált. A Kr. u. 4. században már megjelent a vendégfogadó (xenodochium), amelyet a kolostorok, vagy a püspöki lak mellé építettek. Ezt követték a szegényházak (ptochium vagy ptochotrophium), árvaházak (orphantotrophium), lelencházak (brephotrophium) és a kórházak. A korszak egyházi vagyonának rendeltetését a Kr. u. 4. században élt Nagy Szt. Vazul, cesareai érsek az alábbiak szerint összegezte: „Isten az egyeseket csak megbízza a vagyon kezelésével, mert a vagyont közösen az egész emberiség számára adja."

Az egyházi vagyont 4 részre osztották. Az első rész a püspöké, a második a papságé, a harmadik a szegényeké, a negyedik rész pedig az istentisztelet szükségleteinek fedezésére szolgált. A püspökök mindent elkövettek, hogy a segítségükre rendelt diakónusok és diakonisszákkal együtt a szegényekről életükben és halálukban gondoskodjanak. Ez a gondoskodás megvédte az aggastyánt, a beteget, az árvát, az özvegyet és a gyermeket egyaránt. ${ }^{80}$ Róma örököse, a Bizánci Birodalom pedig létrehozott egy olyan egyedülálló „szociális ellátórendszert”, amely évszázadokon

\footnotetext{
Székely (2015): i. m. 97-98.

Péter (2005): i. m. 108-109.

Pálos (1934): i. m. 17-18.
} 
át kiegyensúlyozottan müködött, és példaképe lehetett (volna) nemcsak a középkori Nyugat-Európának, hanem még korunknak is számos tanulsággal szolgálhat. ${ }^{81}$

\section{Összegzés: az ókori Hellász és a Római Birodalom szociális gondoskodásának jelentősége és hatása}

Az egyes emberek nyomorának enyhítése, a szegények, a nincstelenek, az elesettek felé forduló könyörületesség - vagyis a keresztény értelemben vett irgalmasság - alapvetően nem tartozott az ókori Hellász, a Római Birodalom vagy azok gazdag állampolgárainak célkitűzései közé. A görög-római világ euergetizmusa ugyanis elsődlegesen mindig a városi közösségek egésze felé irányult, vagy ritkább esetben egyes társadalmi csoportok segélyezését célozta meg. A jobbára csak a városi lakosság szegény rétegeinek kijáró alkalmi vagy rendszeres segélyezések során így a gazdag jótevők, a jótevő szerepében fellépő uralkodó, illetve az uralkodó személyén keresztül maga az állam, nyilvánvalóan csak a szegények ama csoportjainak támogatására mutatott hajlandóságot, amelyeket a vezető rétegek felfogása erre még érdemesnek minősített. ${ }^{82}$ Hellászban elvárás volt a szabad polgárok részéről, hogy a közérdekből teljesített katonai szolgálat vagy a háború alatt bekövetkezett sérülésük, haláluk esetén ők vagy hátramaradott családtagjaik (özvegyeik, árváik) valamilyen „állami” ellátásban részesüljenek. Rómában ugyanezt az igényt fogalmazták meg a veteránok és a vezetők, ezt az igényt a lehetőségek függvényében teljesítették. Ebből azt a megalapozott következtetést vonhatjuk le, hogy a modern kor hadigondozásnak elözménye egészen az ókori Hellászig és a Római Birodalomig vezethetö vissza. Azonban az emberszeretet vagy filantrópia nem a keresztény egyház találmánya. Azt már a klasszikus Hellászban és a pogány Rómában is a civilizált emberi lény alapvető tulajdonságának tartották. Azonban a kereszténység megjelenése előtt az egyén szintjén a minden lehetséges módon segíteni akarás szándékát, míg társadalmi szinten a közösség rossz sorban élő tagjainak, különösen a betegeknek, öregeknek, özvegyeknek és árváknak a támogatását értették rajta. Míg a „pogányokat" a szegényeknek történő adakozásban többnyire az együttérzés és a társadalom tagjainak elismerésének elnyerése motiválta, addig a keresztényeknek már ennél több okuk volt a jótékonykodásra. Úgy érezték, hogy embertársaik segítésével is Istent szolgálják.

81 Józsa László: A szociális ellátás rendszere a Bizánci Birodalomban (Történelmi visszapillantás), Esély, (2007/2) 63-65. www.esely.org/kiadvanyok/2007_2/JOZSA.pdf (Letöltve: 2018. 04. 10.);

A bizánci császárok, mint „Isten földi képviselői, a jóakarat és a kegyelem megtestesítői” kötelességüknek tartották a jótékonykodást. Mai szemmel is modernek tűnő intézkedéseik között szerepelt, hogy már a Kr. u. 6. században kolostort és fogadót építettek az örömlányok megmentésére és jó útra térítésére. Az egyes egyházmegyék által létesített karitatív intézményeket adományokkal támogatták. Általános volt, hogy a polgárok is rendszeres adományokkal járultak hozzá szegénysorsú polgártársaik, továbbá az utazók és a zarándokok ellátásához. Mary Cunningham: Hit a bizánci világban, Scolar Kiadó, Budapest, 2013, 72.

82 Szlávik (2007): i. m. 29. 
A jócselekedetet végrehajtó keresztények azonban tetteikkel Istent követték: „Az Emberfia sem azért jött, hogy neki szolgáljanak, hanem hogy ő szolgáljon másoknak, és odaadja az életét, váltságul sokakért. (Mt 20,28; Mk 10, 45)" 83

\section{Felhasznált irodalom}

Bajánházy István: Az állami pénzügyek a római köztársaságban, tansegédlet, 2014. www.scribd.com/document/366110589/azallamipenzugyekromaikoztarsagbanbi2014 (Letöltve: 2018. 04. 10.)

Berzsenyi Emese: A társadalmi gondoskodás és tanítás történelmi elöképei, Iskolakultúra,

25 (2015/9) 100-110. DOI: https://doi.org/10.17543/ISKKULT.2015.9.100

Boden, Martina: Krónika Kézikönyv: Európa, Magyar Könyvklub, Budapest, 2001.

Brósz Róbert - Pólay Elemér: Római jog, Nemzeti Tankönyvkiadó, Budapest, 1991.

Buday Árpád: Római felirattan, Szerzői kiadás, Stief Jenő és Társa Könyvsajtója, Kolozsvár, 1914.

Cunningham, Mary: Hit a bizánci világban, Scolar Kiadó, Budapest, 2013.

Erdődy János: Qui missilia iactant in vulgus - A nép közé történő pénzszórás a római jogban, Pázmány Péter Katolikus Egyetem Jog- és Államtudományi Kara, Doktori Értekezések 11., Pázmány Press, Budapest, 2014. http://mek.oszk. hu/17000/17014/17014.pdf (Letöltve: 2018. 04. 01.)

Fischer, Josef: Welfare services for disabled veterans and surviving dependents in Classical Athens, Kraków, 2017, http://independent.academia.edu/JosefFischer (Letöltve: 2018. 04. 10.)

Grüll Tibor: A Római Birodalom gazdasága, Gondolat Kiadó, Budapest, 2017. Hahn István: A hadművészet ókori klasszikusai, Zrínyi Katonai Kiadó, Budapest, 1963. Hajdu Lajos - Horváth Pál - ljjas József - Nagyné Szegvári Katalin - Zlinszky János - Stipta István: Általános jogtörténet, Tankönyvkiadó, Budapest, 1991.

Holczhammer János: A clientela valószínú eredete, mivolta és fejlődése a római köztársaság korában, A dunántúli evangélikus egyházkerületi lyceum, államilag segélyezett főgymnasium és bölcsészet-theologiai főiskola értesítője az 1900/1901. évi tanévröl, Röttig Gusztáv Könyvnyomdája, Sopron, 1901, https://library. hungaricana.hu/hu/view/Sopron_31441_evangelikus_liceum_31491_1900/?query=patronus\&pg=2\&layout=s (Letöltve: 2018. 04. 10.)

Józsa László: A szociális ellátás rendszere a Bizánci Birodalomban (Történelmi visszapillantás), Esély, (2007/2) 63-76. www.esely.org/kiadvanyok/2007_2/JOZSA.pdf (Letöltve: 2018. 04. 10.)

Kalla Gábor: Háború és béke az Ókorban, Múlt-kor Történelmi Magazin, 2010, http:// mult-kor.hu/20100518_haboru_es_beke_az_okorban (Letöltve: 2018. 04. 10.)

Kató Péter: Illúziók a hellénisztikus polisokban, Ókor folyóirat az antik kultúrákról, 16 (2017/1) http://okorportal.hu/folyoirat/archivum/2017-xvi-evfolyam/20171-illuziok (Letöltve: 2018. 04. 10.)

Kovács (Karner) Károly: Hellenizmus, Róma, zsidóság, Útitárs, Köln-Bécs, 1969.

83 Cunningham (2013): i. m. 70. 
Krawczuk, Aleksander: Római császárok, Interpress, Budapest, 1988.

Kristó Katalin: Tervek és a valóság - A pénzbeli családtámogatási ellátások vizsgálata a kormányprogramok tükrében, Doktori (PhD) értekezés, Nemzeti közszolgálati Egyetem Közigazgatás-tudományi Doktori Iskola, Budapest, 2015. DOI: https:// doi.org/10.17625/NKE.2015.020

Lakner Zoltán: Szociálpolitika (PPKE Vitéz János Kar), Szent István Társulat, az Apostoli Szentszék Könyvkiadója, Budapest, 2012, https://btk.ppke.hu/uploads/articles/288257/file/Szocpol.pdf (Letöltve: 2018. 04. 10.)

Lampe, Peter: Social welfare in the Greco-Roman world as a background for early christian practice, Acta Theologica, (2016) Suppl. 23: 1-28. DOI: https://doi. org/10.4314/actat.v23i1S.1

Manius Curius Dentatus, A Pallas nagy lexikona, www.arcanum.hu/en/online-kiadvanyok/Lexikonok-a-pallas-nagy-lexikona-2/cs-60BB/curius-dentatus-6790/ (Letöltve: 2018. 04. 10.)

Molnár Margit: Töredékek a szociális gondoskodás ókori történetéből, Esély, (1992/3) 93-103. www.esely.org/kiadvanyok/1992_3/toredekekaszocialis.pdf (Letöltve: 2018. 04. 10.)

Németh György: Görög-római szöveggyüjtemény, Osiris Kiadó, Budapest, 2011. www. tankonyvtar.hu/hu/tartalom/tamop425/2011_0001_520_gorog_romai_szovegygyujtemeny/ch158.html (Letöltve: 2018. 04. 10.)

Németh György: Görög ünnepek, História, 14 (1992/10) 3-5.

Németh György: Hogyan nyerjük meg a választásokat? Politikai propaganda a köztársaságkori Rómában, Médiakutató, 2005 tavasz, www.mediakutato.hu/ cikk/2005_01_tavasz/01_hogyan_nyerjuk/ (Letöltve: 2018. 04. 10.)

Pálos Károly: Szegénység Szegénygondozás, Martineum Könyvnyomda Rt., Szombathely, 1934, http://mtdaportal.extra.hu/books/palos_karoly_szegenygondozas.pdf (Letöltve: 2018. 04. 10.)

Pecz Vilmos (szerk.): Ókori Lexikon, Dimissio, www.arcanum.hu/hu/online-kiadvanyok/ Lexikonok-okori-lexikon-CA894/ (Letöltve: 2018. 04. 10.)

Petruska Ferenc: Nemzetközi rekonverzió jogtörténete, Hadtudományi Szemle, 10 (2017/2) 506-519. http://real.mtak.hu/80371/1/17_2_alt_petruska_2.pdf (Letöltve: 2018. 04. 10.)

Péter Orsolya Márta: „Alimenta” A családpolitika és a gyermekes családoknak nyújtott állami támogatás előképei a klasszikus Rómában, Sectio Juridica et Politica, Miskolc, Tomus XXIII/1. (2005) 91-110. www.matarka.hu/koz/ISSN_0866-6032/ tomus_23_1_2005/ISSN_0866-6032_tomus_23_1_2005_091-110.pdf (Letöltve: 2018. 04. 10.)

Rácz Árpád: Beszélgetés Kertész Istvánnal (Az ókortörténet alapkérdései), Rubiconline, www.rubicon.hu/magyar/oldalak/az_okortortenet_alapkerdesei (Letöltve: 2018. 04. 10.)

Rostáné Riez Andrea: A közösségi gazdálkodás érvényesítése a szociális szolgáltatások területén, különös tekintettel a családok támogatására, Doktori (PhD) értekezés, Nyugat-magyarországi Egyetem, Sopron, 2014. DOI: https://doi.org/10.13147/ NYME.2014.034 
Sarkady János: Szociálpolitika az ókori Athénben, História, 19 (1997/2) 11-13. www. tankonyvtar.hu/en/tartalom/historia/97-02/ch02.html (Letöltve: 2018. 04. 10.)

Sáry Pál: A mezőgazdasági munka erkölcsi elismerése az ókori Rómában, Miskolci Jogi Szemle, 12 (2017/2) 519-525. különszám, www.mjsz.uni-miskolc.hu/2017kulon2/51_sarypal.pdf (Letöltve: 2018. 04. 10.)

Szabó György: Sötétben tündöklőbb a fény. Római szállóigék és aforizmák, Dacia, Kolozsvár-Napoca, 1975, www.arcanum.hu/hu/online-kiadvanyok/Gondolattarkristo-nagy-istvan-gondolattar-1/1800-elott-szuletett-szerzok-2/valerius-maximus-i-szd-elso-ele-romai-tortenetiro-8A5/ (Letöltve: 2018. 04. 10.)

Szepessyné Judik Dorottya: A hallássérült emberek magyarországi mozgalmának története nemzetközi kitekintéssel, in: Hegedüs Lajos - Ficsorné Kurunczi Margit - Szepessyné Judik Dorottya - Pajor Emese - Könczei György: A fogyatékosságügy hazai és nemzetközi története, Eötvös Loránd Tudományegyetem Bárczi Gusztáv Gyógypedagógiai Kar, Budapest, 2009.

Székely Melinda - Illés Imre Márton (szerk.): Késő római szöveggyűjtemény, JatePress, Szeged, 2013.

Székely Melinda: Szegénység, gyermekszegénység az ókori Rómában, Szegedi görög füzetek 9., Közéleti és politikai viszonyok az antik világban, A Szegedi Görög Nemzetiségi Önkormányzat és a Csongrád Megyei Görögök Kulturális Egyesületének kiadványa a Szegedi Tudományegyetem Ókortörténeti Tanszékének közreműködésével, Szeged, 2015, 89-98. www.szegedigorogok.hu/szegedi-gorog-fuzetek-9/ (Letöltve: 2018. 04. 10.)

Szinai Alexandra: A szociális biztonsághoz való jog, Miskolci Egyetem, Miskolc, 2013, http://midra.uni-miskolc.hu/document/14318/6591.pdf (Letöltve: 2018. 04. 10.)

Szlávik Gábor: „A szegények mindig veletek lesznek” - a szegénység fogalma és társadalmi értékelése az antik szerzőknél, az újszövetségi iratokban és a Kr. u. I-III. század keresztény gondolkodóinál, Egyháztörténeti Szemle, 8 (2007/20) 3-58. http:// egyhaztortenetiszemle.hu/wa_files/eSzemle2007-2.pdf (Letöltve: 2018. 04. 10.)

Szlávik Gábor: Egy elmaradott régió szerepvállalása a kor vallási mozgalmaiban: Közép-Phrygia montanizmusa, Egyháztörténeti Szemle, 7 (2006/1) 3-36. http:// epa.oszk.hu/03300/03307/00013/index.htm (Letöltve: 2018. 04. 10.)

Szoboszlai-Kiss Katalin: A hellenizmus filozófiai mozgalmainak gyökereiről, A kisebb szókratikus iskolák, Jog - Állam -Politika, 3 (2011/4) 135-160. http://dfk-online. sze.hu/images/J\%C3\%81P/2011/4/szoboszlai.pdf (Letöltve: 2018. 04. 10.)

Takáts László: A Rákóczi-szabadságharc egészségügye, 2003, http://mek.oszk. hu/05400/05419/05419.pdf (Letöltve: 2018. 04. 10.)

Tóth Krisztián: Nagy Heródes: zsarnok vagy jótevő? XX. reál- és humántudományi Erdélyi Tudományos Diákköri Konferencia (ETDK), Kolozsvár, 2017, http://etdk. adatbank.transindex.ro/pdf/tothkrisztian.pdf (Letöltve: 2018. 04. 10.)

Tóth László: Vegetius a sorozásról, Hadtudományi Szemle, 7 (2014/3) 208-215. http://epa.oszk.hu/02400/02463/00024/pdf/EPA02463_hadtudomanyi_ szemle_2014_03_208-215.pdf (Letöltve: 2018.04. 10.)

Ürögdi György: Róma kenyere, Róma aranya, Gondolat kiadó, Budapest 1969.

Weinhoffer Judit: A katona-egészségügy szerepe a rehabilitáció XX. századi fejlődésében, Doktori (PhD) értekezés, Nemzeti Közszolgálati Egyetem, Hadtudományi 
Doktori Iskola, Budapest, 2017, http://archiv.uni-nke.hu/feltoltes/ uni-nke.hu/ konyvtar/digitgy/phd/2017/weinhoffer_judit.pdf (Letöltve: 2018. 04. 10.) DOI: https://doi.org/10.17625/NKE.2017.16

Wesch-Klein, Gabriele: Recruits and Veterans, in: Paul Erdkamp (ed.), A companion to the Roman Army, Blackwell Publishing Ltd., Oxford, 2007. DOI: https://doi. org/10.1002/9780470996577.ch25 